\title{
The Criminal Enforcement of the Fraud Mode of Multiple Money (Case study Decision No.61 / Pid.B / 2019 / PN.Blora)
}

\author{
Sumaryono $^{1}$ and Sri Kusriyah ${ }^{2}$
}

Abstract: Fraudulent criminal acts that have been regulated in the Criminal Code (KUHP) with various modes, one of which is fraud by shamans with a multiplied money mode has made law enforcers increasingly have to rack their brains to be able to prove it. This study aims to examine and analyze law enforcement by the judge in decision No.61 / Pid.B / 2019 / PN.Blora with consideration of the criminal elements. The research method used is a sociological juridical approach. The specifications of the study were conducted using descriptive analytical methods. The data used for this study are primary and secondary data. The data consists of primary data and secondary data using field research methods, interviews, and literature studies. Based on the research it was concluded that the case ruling number 61 / Pid.B / 2019 / PN Bla with a fraud case with shamanism practices in the mode of duplicating the judge's money considering that the Defendants have been indicted by the Public Prosecutor with alternative indictments, so the Panel of Judges paid attention to the facts The aforementioned law decides on the first alternative indictment as regulated in Article 378 of the Criminal Code Jo Article 55 paragraph (1) of the 1st Criminal Code by considering the elements of that article.

Keywords: Criminal Law Enforcement; Fraud; Multiple Money.

\section{Introduction}

Article 1 Paragraph (3) The 1945 Constitution of the Republic of Indonesia states that the State of Indonesia is a State of law. Understanding of the rule of law actually means that a State adheres to the teachings and principles of the rule of law in which law is held in high esteem as a guide and determinant of policy direction in carrying out the principles of national and state life. ${ }^{3}$

Law in general is a whole collection of rules or methods in a shared life, the whole about the behavior that applies in a shared life, which can be enforced with a sanction. ${ }^{4}$ The rule of law is aimed primarily at concrete perpetrators, that is, for perpetrators of actual violations, also aimed at public order so as not to fall victim to crime, and so that crime does not occur.

One form of crime that is currently rife in society is fraud with the mode of multiplying money. For the unscrupulous, fraud is not so difficult to do. Fraud can be done simply by having good communication skills so that someone can convince others, either through a series of lies or fictitious words. Now there are so many

\footnotetext{
${ }^{1}$ Student of Master of Law, Sultan Agung Islamic University (UNISSULA), Semarang email maryonoreskrim74@gmail.com

${ }^{2}$ Lecturer of Faculty of Law, Sultan Agung Islamic University (UNISSULA), Semarang

${ }^{3}$ Darmoko Yuti Witanto and Arya Putra Negara Kutawaringin, Judge Discretion An Instrument of Enforcing Substantive Justice in Criminal Cases, (Bandung: Alfabeta, 2013), p. 1.

${ }^{4}$ Sudikno Mertokusumo, Getting to Know the Law, (Yogyakarta: Liberty, 2007), p. 40.
} 
criminal acts of fraud with various modes. This development shows that the level of intellectuality of the perpetrators of fraud is increasingly rampant.

In the case of doubling money in the Criminal Code it is not stipulated more clearly because it is Bank Indonesia (BI) who has the right to duplicate money as a legal payment instrument Doubling means to multiply multiple or multiply the amount from before. So, the amount of money multiplies after it is doubled. Scientifically, the multiplication of money in a supernatural way is only as a mode of crime to get people to collect as much money as possible when there is no such thing. ${ }^{5}$ Fraud is a crime against property. Fraud is regulated in Book II of the Criminal Code (KUHP) in Chapter XXV containing various forms of fraud that are formulated in 20 Articles $^{6}$, wherein fraud in its principal form is regulated in Article 378 of the Criminal Code.

Besides that, fraud by shamans doubling money occurs because many people still believe in mystical things. Evidenced by the many shamanistic practices that are still in demand by many people. Every person who uses the services of a shaman or psychic has a specific purpose. Most of them aim to make their lives successful, get rich quickly, to get a mate, cure illness and others. Belief in these supernatural things which are then used by evil people to reap profits where they pretend to be psychics by acting a little and eventually can fool others. This shamanism mode is sure to prove the number of fraud cases by using shamanism mode. The victims are people who really believe in occult things.

This fraud case with the mode of procurement of money occurred in Blora Regency, which was the mode similarly in the case of the multiplication of money which is a form of fraud with the shamanism mode which generally occurs due to the lack of insight and education that the community has and the community's trust in the shaman who is considered to have the power to be able to help the difficulties that the community faces. Though not all shamans or psychics can help with these difficulties, even some of them only pretend to help but actually can't do anything. As a result many people are deceived and not the convenience they can get but the material or material losses suffered by the victims.

Regarding this criminal act of fraud, the author is interested in conducting research because of the need for in-depth analysis of criminal policy in the case because in the case of the multiplication of money by a shaman as a phenomenon that still occurs in trusting in a community environment that incidentally the invisible influence is still a strong belief in its existence change human life in its essence. And to be able to conduct a juridical study, the writer uses the judge's decision in the case of a criminal act of fraud with a shamanism mode, namely doubling money.

Based on the description on the background of the problem above, a problem statement can be formed: How is the law enforcement by the judge in the decision No.61 / Pid.B / 2019 / PN.Blora with consideration of the criminal elements?

\footnotetext{
${ }^{5}$ Umar Anwar, Criminal Act of Duplication of Money in the Criminal Code (Overview of the Case of the Multiplication of Dimas Kanjeng Taat Privately), DKI Jakarta Kemenkumham Regional Office, Indonesian Legislation Journal Vol.13 No.04, December 2016, p. 370.

${ }^{6}$ Ismu Gunadi and Jonaedi Efendi, Quick and Easy to Understand Criminal Law, Jakarta: Prenadamedia Group, p. 144.
} 


\section{Research Methods}

In this study the authors used the method sociological juridical. Sociological juridical research is research on legal identification and legal effectiveness. In this research the effectiveness in question is a legal study of public awareness, community knowledge and application of law in society. ${ }^{7}$ The specifications of the study were conducted using descriptive analytical methods. The data used for this study are primary and secondary data. To obtain data in this study, data collection methods are used, namely primary data and secondary data. The data that has been obtained is then analyzed by qualitative analysis, namely data analysis by not using numbers, but data obtained through research.

\section{Results and Discussion}

Law enforcement is a process to make legal wishes come true. The so-called legal wishes here are none other than the thoughts of the legislature which are formulated in the rule of law. The rule of law. The formulation of the thoughts of lawmakers as outlined in the rule of law will also determine how law enforcement is carried out. ${ }^{8}$ In principle, the court is passive and only waits for every case submitted to it, or in other words the judge as a law enforcer is prohibited from asking or suggesting a dispute or a problem both criminal and civil to be resolved in court. Although the court is passive to wait for the case, but when the case has been submitted / delegated to him and becomes his authority, the court is forbidden to reject the case on the grounds that there is no or less clear law because the judge is always considered to know the law. ${ }^{9}$

Every case that is submitted to the court must continue to be tried, regardless after being tried later the judge states that the case is not a criminal offense or not within the scope of his competence, then the court must continue to adjudicate, regardless after the judge then states that the case is not a criminal offense or not within the scope of its competence, then the court must declare it in the form of a decision not in the form of a case rejection before trial. ${ }^{10}$

In the case of fraud with the mode of duplication of money in which the results of the authors carry out research in the Blora Court in the form of case decision number 61 / Pid.B / 2019 / PN Bla. Based on the decision by the following methods:

- That this incident was originally a witness of SWADJI SURYANTORO, was told by JIARNO (DPO) that an ustad by the name of YUSUF could bring in billions of ghoib money, then witness SWADJI SURYANTORO told SULIKIN witnesses and SULIKIN witnesses were interested in the next. the cleric who is usually called the cleric of YUSUF wants to bring in ghoib money by giving a wage / compensation in advance of Rp. 40,000,000.00 (forty million rupiah) and witness SULIKIN is interested;

\footnotetext{
${ }^{7}$ Soerjono Soekanto, Introduction to Legal Research, Jakarta: UI Press, 1986, p. 14.

${ }^{8}$ Satjipto Raharjo, Op.Cit, page 25

${ }^{9}$ Article 10 paragraph (1) of Law Number 48 Year 2009 Concerning Judicial Power.

${ }^{10}$ Darmoko Yuti Witanto, Arya Putra Negara Kutawaringin, Judge Discretion An Instrument of Enforcing Substantive Justice in Criminal Cases, Bandung: Alfabeta, 2013, page 21
} 
- That further JIARNO informed Defendant I YUSUF Bin RASTIM and Defendant II BAMBANG AAN WIJONARKO Bin ASEP SUHERMAN there was a person named SULIKIN who wanted to bring in ghoib money, then witness SULIKIN contacted Defendant I YUSUF Bin RASTIM to want to help get the money for Ghoib and Defendant I YUF wanted to help the witness SULIKIN but asked to be sent money first for transportation costs to the house of the witness SULIKIN in Cepu;

- That on Wednesday, February 6, 2019 around 07.47 WIB, witness SULIKIN sent money to Defendant I YUSUF Bin RASTIM to be transferred to BNI Bank account number 433801005164531 in the name of RINI YUSELA in the amount of $\mathrm{Rp} 1,500,000.00$ (One million five hundred thousand rupiah) then around 13.10 WIB Witness SULIKIN transfers again to the same account number Rp.500,000.00 (Five hundred thousand rupiah);

- That on Friday, February 8, 2019 around 03.30 WIB, Defendant I YUSUF Bin RASTIM together with Defendant II BAMBANG AAN WIJONARKO ASEP SUHERMAN Bin came from Subang, West Java, directly to the residence of SULIKIN Witness precisely in the room where the futsal court rests belong to Witness SULIKIN in Wonorejo Village Lorong VII RT 08 RW 13 Cepu Village Cepu District Blora Regency then Defendant I YUSUF Bin RASTIM asked for the requirements for the ritual, namely 2 (two) large boxes, 2 (two) pieces of black sarong, and a black cloth / white blanket to cover cardboard, 2 (two) cups filled with tea, 2 (two) cups filled with coffee, 1 (one) sprite beverage bottle, 1 (one) cigarette pack of clove red salt cellar;

- That after all the ritual requirements were provided in a closed room then Defendant I YUSUF Bin RASTIM began the ritual and took out Joshua and burned it with a match then turned off the room lights so the room went dark, while waiting for Defendant I YUSUF Bin RASTIM to perform the ritual in a closed room, Defendant II BAMBANG AAN WIJONARKO Bin ASEP SUHERMAN convinced Witness SULIKIN, WitnesS SWADJI SURYANTORO and JIARNO by saying to believe in the defendant YUSUF because Defendant YUSUF had succeeded in bringing in ghoib money through science and ritual;

- That further Defendant I YUSUF Bin RASTIM ordered Witness SULIKIN and JIARNO to enter the dark room and then Defendant I YUSUF Bin RATIM lit a match so that it appeared dim. Defendant I YUSUF Bin RATIM subsequently showed Rp50,000.00 denomination (fifty thousand rupiahs) ) spread over the cardboard cloth because the light was not bright and dim, the money was seen filling two boxes, then Defendant I YUSUF Bin RATIM took the money and distributed it on the floor then Witness SULIKIN and JIARNO were told to take it and were told to bring the money to prove its authenticity when the SULIKIN Witness received Rp.400,000.00 (Four hundred thousand rupiah) while JIARNO received Rp.300,000,00 (Three hundred thousand rupiah) after a while Defendant I YUSUF Bin RATIM left the room and requested that the room be locked and that the SULIKIN Witness be told to wait until the afternoon to collect large amounts of money in the 2 (two) boxes;

- That after the ritual of Defendant I YUSUF Bin RATIM asked for a wage / reward of Rp. 40,000,000.00 (forty million rupiah), but at that time SULIKIN's Witness was only able to provide cash compensation of $\mathrm{Rp} .7,000,000.00$ (seven million rupiah) 
in cash and Rp.4,000,000.00 (Four million rupiah) by way of transfer and after that the Defendants promised to return in the afternoon to open and take the money in the box, but after the afternoon they did not come again so finally the Witness SULIHIN opened room and open 2 (two) boxes which are found to be empty;

- That the Rp50,000.00 (fifty thousand rupiah) denomination shown by Defendant I YUSUF Bin RATIM was spread over the cardboard cover cloth and seen to fill two boxes was SULIKIN's own witness money sent to Defendant I YUSUF Bin RATIM and SULIKIN's Witness had given compensation for Defendant I YUSUF Bin RATIM in the total amount of Rp.13,000,000.00 (Thirteen million rupiah);

- That all of this was only a series of false words from Defendant I YUSUF Bin RASTIM and Defendant II BAMBANG AAN WIJONARKO Bin ASEP SUHERMAN so that the SULIKIN Witness would trust and be willing to hand over money to the Defendants;

- Whereas finally the SULIKIN Witness could contact the Defendants through Defendant II BAMBANG AAN WIJONARKO Bin ASEP SUHERMAN so that he and Defendant I YUSUF Bin RATIM came back to Cepu, then on Monday 11 February 2019 around 04.30 WIB The Defendants came to the Witness SULIKIN's house at CULDU in return. Cepu was then secured together with witness SWADJI SURYANTORO and taken to the Cepu Sector Police for further investigation.

That the defendant's actions were charged by the Public Prosecutor with an alternative indictment, namely Article 372 of the Criminal Code concerning embezzlement and Article 378 of the Criminal Code concerning Fraud. The Public Prosecutor in the trial presented witnesses who gave statements under oath according to their respective religions. ${ }^{11}$

In this case the judge considers that the Defendants have been indicted by the Public Prosecutor with an alternative form of indictment, so that the Panel of Judges taking into account the legal facts above directly elects the first alternative indictment as regulated in Article 378 of the Criminal Code Jo Article 55 paragraph (1) to -1 of the Criminal Code, the elements of which are as follows:

- Element One "Who"

Whoever points to a legal subject or person who commits a criminal offense from a criminal offense and that person is a person who is capable of being responsible and can be held accountable for his actions legally which here are anyone or legal subjects as perpetrators of a criminal act whose actions can be accounted for according to law. Defendant I YUSUF Bin AIm RASTIM and Defendant II BAMBANG AAN WIJONARKO Bin Alm ASEP SUHERMAN with all their identities as stated in the Indictment Letter is seen as a rights and obligation holder and it turns out that during the trial the Defendants were physically and mentally healthy so that they could properly participate in the trial. .

- Second Element "With the intention to benefit oneself or others by opposing rights"

\footnotetext{
${ }^{11}$ Decision on Case Number 61 / Pid.B / 2019 / PN Bla
} 
Considering, that the element "with the intention to benefit oneself or others against the rights" contained in Article 378 of the Criminal Code is not an element of behavior, but an element aimed at the heart or intention or intention of the offender to benefit himself or others with unlawful means by using false names or false circumstances, deception or a series of lies.

- Third Element "By using a false name or false situation, by deception or by fabricating false words, persuading people to give an item, making a debt / writing off a debt"

The element of using false names or false circumstances, with deception, or fabrication of false words, persuading people to give away an item, making a debt / removing receivables is an alternative element. Considering, that because of the deception and series of lies from the Defendants, the victim, SULIKIN, gave money to the Defendants.

Based on legal facts, it is clearly known that the Defendants cooperated in carrying out deception and a series of false words. That because these elements are alternative, if one or several elements are fulfilled, those elements are considered to have been proven entirely. Considering, that based on the legal basis and legal facts above, the Panel of Judges believes that this element has been fulfilled.

- Fourth Element "People who do, who ordered to do, and who participated to do the deed"

Considering, that based on the legal facts described above it is known that the Defendants have their respective roles in the criminal acts committed in which the roles of each defendant have the same purpose and share in the criminal acts committed.

In this case the judge stated Defendant I YUSUF Bin Alm RASTIM and Defendant II BAMBANG AAN WIJONARKO Bin Alm ASEP SUHERMAN mentioned above, was proven legally and convincingly guilty of committing the crime of "participating in fraud" as in the first alternative indictment. Sentencing the Defendants, therefore, by imprisonment for Defendant I YUSUF Bin Alm RASTIM for 1 (one) year, for Defendant II BAMBANG AAN WIJONARKO Bin Alm ASEP SUHERMAN for 10 (ten) months. ${ }^{12}$

So it is clear that the sentence handed down to the defendant is a fraud with the mode of doubling money in shamanistic practices, including light. Because the decision is in the form of imprisonment for 10 (ten) months. But all of that has become the authority of the Panel of Judges based on conviction and legal considerations as well as the facts in the trial besides that it is also based on a principle which states that the Panel of Judges only has the authority to impose a criminal offense not to be more than the demands of the Public Prosecutor.

In this case the judge has carried out which positivistic flow reduce human existence in the process of life which is controlled by the certainty of legal causation. Positivism in law means that law is posited as the highest status among various norms (the supreme of law), which consists of a long series of statements about various acts that are identified as legal facts with consequences called legal consequences. ${ }^{13}$

\footnotetext{
12 Decision on Case Number 61 / Pid.B / 2019 / PN Bla

${ }^{13}$ Hans Kelsen,Essays in Legal and Moral Philosophy, transferring Language B. Arief Sidarta, Law and Logic, Alumni, Bandung, 2006, p. 33
} 


\section{Closing}

\subsection{Conclusions}

In the case ruling number 61 / Pid.B / 2019 / PN Bla with a criminal fraud case with a shamanistic practice of duplicating money the judge considered, that the Defendants had been charged by the Public Prosecutor with an indictment in the form of an alternative, so the Panel of Judges with regard to the facts The aforementioned law directly elects the first alternative indictment as regulated in Article 378 of the Criminal Code Jo Article 55 paragraph (1) of the 1st Criminal Code, the elements of which (1) Whoever, (2) With the intent to benefit oneself or others by opposing rights, (3) By using a false name or false situation, by deception or by fabricating lies, persuading people to give an item, making a debt / write off a debt, (4) People who do, who order to do, and who participate do the deed, by imposing a criminal for 10 (ten) months.

\subsection{Suggestions}

- For the authorities to give an appeal to all members of the community, especially Blora Regency to always be aware of the lure of relatives or new people about the existence of unreasonable and unjustified duplication of money and is clearly a fraudulent crime that has rules law;

- The House of Representatives (DPR) and the Government need to build a commitment to immediately enact the RKUHP so that the legal substance regulating the prohibition of paranormal practices can be pursued by law enforcement based on concept reformation so that it can be an appropriate solution in tackling crime against a background of false paranormal practices ;

\section{References}

\section{Book}

[1] Darmoko Yuti Witanto dan Arya Putra Negara Kutawaringin, Diskresi Hakim Sebuah Instrumen Menegakkan Keadilan Substantif dalam Perkara-Perkara Pidana, (Bandung: Alfabeta, 2013)

[2] Hans Kelsen, Essays In Legal and Moral Philosophy, alih Bahasa B. Arief Sidarta, Hukum dan Logika, Alumni, Bandung, 2006

[3] Ismu Gunadi dan Jonaedi Efendi, Cepat dan Mudah Memahami Hukum Pidana, Jakarta: Prenadamedia Group

[4] Soerjono Soekanto, Pengantar Penelitian Hukum, Jakart a : UI Press, 1986

[5] Sudikno Mertokusumo, Mengenal Hukum, (Yogyakarta: Liberty, 2007)

\section{Regulations}

[1] The 1945 Constitution of the Republic of Indonesia

[2] Criminal Law Book

[3] Criminal Procedure Code

[4] Act No. 48 of 2009 concerning Judicial Power 


\section{Journal}

[1] Umar Anwar, Tindak Pidana Penggandaan Uang Dalam Kitab Undang-Undang Hukum Pidana (Tinjauan Kasus Penggandaan Uang Dimas Kanjeng Taat Pribadi), Kantor Wilayah Kemenkumham DKI Jakarta, Jurnal Legislasi Indonesia Vol.13 No.04, Desember 2016

\section{Documents}

[1] Decision on Case Number 61 / Pid.B / 2019 / PN Bla 